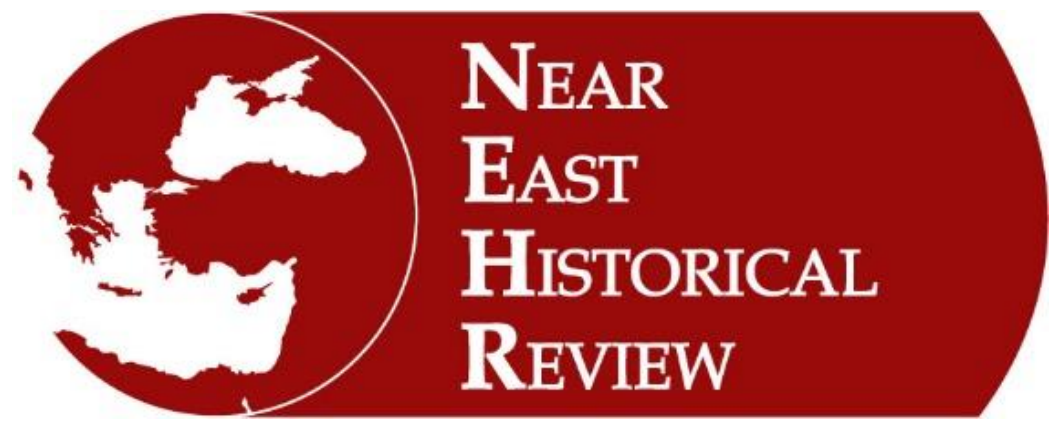

\title{
XIX. YÜZYILDA TRABZON VILAYETI'NDE KAÇAKÇILIK VE KAÇIRILAN EMTİALAR
}

Smuggling and Missed Commodities in the $19^{\text {th }}$ Century Trabzon Province

\section{Kubilay Hamzaoğlu}

Ondokuz Mayıs Üniversitesi, Türkiye

e-mail: hamzaoglukubilay@gmail.com

ORCID ID: orcid.org/0000-0001-6569-1680

Near East Historical Review

10/2, April - Nisan 2020

e-ISSN: 2717-6363 (Online)

www.nehrreview.com

\footnotetext{
Article Type - Makale Türü : Research Article / Araştırma Makalesi

Received Date - Geliş Tarihi : $\quad$ 07.02.2020

Accepted Date - Kabul Tarihi : $\quad 15.03 .2020$

Pages - Sayfa : 205-225

doi : http://dx.doi.org/10.29228/nehrreview.42830
}

Citation - Attf : Kubilay Hamzaoğlu, "XIX. Yüzyilda Trabzon Vilayeti'nde Kaçakçilik ve Kaçirilan Emtialar", Near East Historical Review, 10/2, April 2020, pp. 205-225 



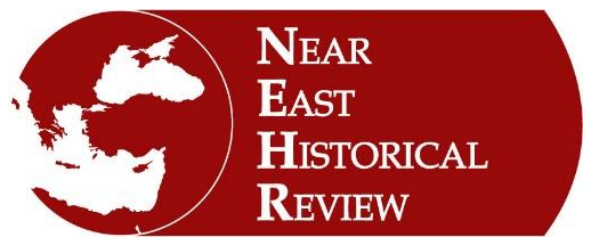

Near $\boldsymbol{E}$ ast $\boldsymbol{H}$ istorical Review

10/2, April - Nisan 2020

205-225

\title{
XIX. YÜZYILDA TRABZON VILAYETI'NDE KAÇAKÇILIK VE KAÇIRILAN EMTİALAR*
}

\author{
Smuggling and Missed Commodities in The $19^{\text {th }}$ Century Trabzon Province
}

\author{
Kubilay Hamzaoğlu \\ Ondokuz Mayıs Üniversitesi, Türkiye
}

\section{$\ddot{O} \mathbf{z}$}

Osmanlı Devleti, geniş sınırları olan buna müteakip pek çok limana, ticari yollara ve ticaret imkânlarına sahip bir coğrafyayı yöneten önemli bir konumdaydı. Devletin bu coğrafi özelliğinden ve aktif ticari işleyişinden dolayı kaçakçılık konusu da devleti meşgul eden bir sorunsal olarak karşımıza çıkmaktadır. $\mathrm{Bu}$ durum devletin var olan yerel ticaretini etkilediği gibi yabancı devletlerle olan ticari münasebetlerini de etkilemiştir. Aslında kaçakçılık olgusu sadece ticari bir etki meydana getirmekle kalmamış bizzat devletin çok uluslu şirketlere karşı siyasi politikalarını da etkilemiştir. XIX. yüzyılda Osmanlı Devleti'nde bu durumun örneği tütün kaçakçılığında kendisini gösteren Reji şirketidir. Tuz kaçakçılığında ise bu durumun örneği Duyun-1 Umumiye İdaresi'dir. Osmanlı Devleti'nde meydana gelen kaçakçılık olgusunun pek çok nedeni vardır. Ancak biz bu çalışmamızda; XIX. yüzyıl da Trabzon Vilayeti'nde yapılan muhtelif emtia kaçakçılığının tür ve cinslerinin neler olduğu, kaçırılan bu emtiaların hangi yöntem ve tekniklerle yapıldığını tespit etmeye çalışmaktır.

Anahtar Kelimeler: Kaçakçılık, eşkıya, silah, tütün, tuz

\begin{abstract}
There were many ports and trade routes within the borders of the Ottoman Empire. So the Ottoman Empire was in a strategic position. Due to this geographical feature and active commercial operation of the Ottoman Empire, smuggling is a problem that occupies the state. This situation not only affected the local trade of the state, but also affected the commercial relations with foreign states. Smuggling has not only affected trade but also played a decisive role in the state's political policies against multinational companies. The example of this situation in the Ottoman Empire in the 19th century is the Reji Company, which manifested itself in tobacco smuggling. In salt smuggling, the example of this situation is the Duyun-1 Umumiye Administration (The Ottoman Public Debt Administration). There are many reasons for the smuggling phenomenon in the Ottoman Empire. However, in this study; We tried to determine the types and types of various commodity smuggling carried out in Trabzon Province in the 19th century and by which methods and techniques these hijacked commodities were made.
\end{abstract}

Keywords: Smuggling, bandit, gun, tobacco, salt, mine

\footnotetext{
* Bu makale, yazarın, 2019 senesinde Ondokuz Mayıs Üniversitesi Sosyal Bilimler Enstitüsünde yapılan “Trabzon Vilayeti'nde Kaçakçılık (1855-1908)" isimli yayınlanmamış yüksek lisans tezinin bir bölümünün yeniden gözden geçirilmesi suretiyle üretilmiştir.
} 


\section{GİRIŞ}

Kaçakçılık; bir emtianın yasalara veya kanunlara aykırı olarak gizli bir şekilde bir ülkeye, coğrafyaya ya da bir devletin sınırları içerisine sokmak veyahut çıkarmak olarak tanımlanabilir. Bu işi yapan şahıs ve zümrelere kaçakçı denilmektedir Kaçakçılık tarihi, ekonomik değere sahip emtianın ticaret sonucunda ilk olarak vergilendirilmesine kadar götürülebilir. ${ }^{1} \mathrm{Bu}$ durum kaçakçılık faaliyetlerinin her bölgede yapıldığı anlamına gelmektedir. Kaçakçılık olgusu, Osmanlı Devleti'nin de gündemini meşgul eden bir sorundur. Osmanlı klasik döneminde Karadeniz Bölgesi'nde kaçakçılık faaliyetleri sınırlı kalmıştır. Bunun öne çıkan birkaç sebebi vardır. Bunlar; Karadeniz'in bir iç deniz halinde bulunması, devletin kendi iç ihracat yasaklamalarının olması, devletin yabancı devletlerle olan siyasi, sosyal, ekonomik ve askeri ilişkilerinde kendisini etkileyebilecek bir gücün olmadığına inanması ve Karadeniz Bölgesi’nde ticari faaliyetlerin kısıtlı olmasındandır. Klasik döneme nazaran XIX. yüzyılda ise Karadeniz'in bu hüviyetinin değişmesi, uluslararası ticarete açılması ve ticari metalardaki yasaklamaların artmasından dolayı kaçakçılık faaliyetleri görülmeye başlanmıştır. Bununla beraber Tanzimat reformları dolayısıyla devlet mekanizmasının yabancı müdahalesine açık hale gelmesi neticesinde de kaçakçılık faaliyetlerinde bir artış meydana gelerek kaçakçıların yöntem ve teknikleri değişme ve gelişme göstermiştir. Trabzon Vilayeti dâhilinde ticaretin artma potansiyelini XVIII. yüzyılın başlarından itibaren öngören yabancı devletler, tacirlerin haklarına, taleplerine, şikâyetlerine cevap vermek amaciyla bu vilayet dâhilinde konsolosluk ${ }^{2}$ açma faaliyetlerine başlamışlardır. ${ }^{3} \mathrm{Bu}$ durum XIX. yüzyılda ithalat ve ihracat oranlarının gelişmesini sağlamıştır. Tabi ki bu durumu oluşturan salt konsolosluk etkeni değildir. Ticaretin güvenliği, ticaret anlaşmaları, yol ve güzergâhların iyileştirme çabaları vilayetteki iskele ve limanların konumu yani ulaşımdaki yakınlık ve kolaylık ayrıca tüccara sağlanan imkânlar ki bunlar; gümrük indirimleri, malların korunması için depolama, konaklama gibi etkenlerdi. Ticaretin çok yönlü boyutu tüccar, sanayici ve girişimci kadroları yatırım ve ticaret yapabilecek alanlara yönlendirmiştir. Bu alanlardan birisi XIX. yüzyılda Karadeniz'e kıyısı olan bilhassa Trabzon Vilayeti'ni kapsayan, kıyı liman ve iskeleler olmakla beraber kıyıya yakın bölgelerde de yatırımcılar, ticaret ve yatırım amaçlı kurum ve kuruluşlar oluşturmuşlardır. Bunlardan bir kaçı şu şekildedir; deniz ticareti için oluşturulmuş acenteler, İdare-i Mahsusa, Gürcü Osmanlı kumpanyas1, Nemçe kumpanyas1, Rus kumpanyası, Yunan kumpanyası, Fransız Pake kumpanyas1, Fransız Messageries kumpanyası, İtalya kumpanyası ve daha birçok acente kurulmuştur. ${ }^{4}$ Ayrıca Fransızlar tarafından deniz ulaşımı, fenerler idaresi, bankacılık ve reji idaresi gibi yatırımlar yapılmıştır. ${ }^{5}$ Bununla birlikte Trabzon şehrinde beş ticarethane bulunuyordu. Bunlar Lacheze-Arnaud, Marcopoly, Syriant, İngiliz ve Catenaki ticarethaneleriydi. ${ }^{6}$ Samsun'da ise Fransız ve Samsun ticaret odaları mevcuttu. ${ }^{7}$ Bu yapılar yasal ekonomik planlama ve işlerliğin yanı-sıra yasadışı olan kaçakçılık faaliyetlerini de etkilemiştir. Zira her ne kadar yerli ve yabancı yatırımcı hükümetin gözünde yasal faaliyetlerde bulunmak istese de vergi ve gümrük işlemlerinden kaçmanın da bir yolunu aramıştır. Kaçakçılık yapan yabancı tüccarlar olduğu gibi yerli tüccarlarda bu konuda aktifti. Kaçakçıllk yapan yabancı kumpanyalara ait bir belgede, Rusya vapuruyla Batum'a ihraç edilen harp mühimmatının ele

\footnotetext{
${ }^{1}$ Kubilay Hamzaoğlu, Trabzon Vilayeti’nde Kaçakçılık (1855-1908), (Yayımlanmamış Yüksek Lisans Tezi), Ondokuz Mayıs Üniversitesi Sosyal Bilimler Enstitüsü, Samsun 2019, s. 4.

${ }^{2}$ Konsolosların görevleri bulundukları bölgelerde himayelerindeki halk, tüccar ve ticareti korumak, bölgenin iktisadi, ticari hayatını öğrenmek ve dâhil olmak, ayrıca görev tanımı dışında siyaseten bilgi edinmektir.

${ }^{3}$ Trabzon Vilayet-i Salname (Bundan sonra TSV) 1901. s.226.

${ }^{4}$ TSV, 1898. s. 284-287.

5 Özgür Yılmaz, “19. Yüzyılda Trabzon'da Fransız Ticareti ve Yatırımları”, Karadeniz Incelemeleri Dergisi, 8/15, 2013, s. 73.

6 Özgür Y1lmaz, “19. Yüzyılda Trabzon'da Fransız Ticareti ve Yatırımları”, s.52.

${ }^{7}$ Annuarie Oriental, 1902. s. 300.
} 
geçirildiği muhtelif yerlere gaz taşıyan İngiliz bandralı vapurlarla silah kaçakçılığı yapılması ile ilgili verilere ulaşmak mümkün olmuştur. ${ }^{8}$ Başka bir belgede ise, kaçakçılık konusunda etnik farklılı̆̆ın olmadığı, amaç ve hedef aynı ise farklı etnik ve grupların çıkarlarını koruduğu bu yüzden kaçakçıllğın bir sistem olarak gelişme gösterdiğini belirlemekteyiz. Söz konusu belge, Osmanlı ülkesine silah sokan ve Triyeste'de silah kaçakçılığından yargılanan Merzek Romano'nun Trabzon'da mukim iki suç ortağından birinin yakalanması ve yakalanan şahsın yargılanabilmesi için mahkeme evraklarını gönderilmesi ile ilgiliydi ${ }^{9}$. Kaçakçılık yapan yabancı tüccarların yasadışı faaliyetleri her zaman kendi çevresi ve irtibatta olduğu ekiple alakalı olmamıştır. Bazen yapılan faaliyet amacını aşarak iki devleti karşı karşıya getirerek notalara sebep olmuştur $^{10}$. Bu durum kaçakçılık faaliyetlerinin bireysellikten çıkıp devletlerin ortak meselesi haline gelmesini, kaçakçılık organizasyon ve fiillerinin ne kadar tehlikeli, sınırlarının ne kadar geniş olduğunu bizlere sunması açısından önemlidir.

Trabzon Vilayeti sınırlarına tekrardan dönecek olursak, bir "arz" da her türlü eşya ve şahsı taşımaktan çekinmeyen yerli kaçakçıların yakalananlarından bazıları sorgularında, iş bulamayıp aç ve sefil kaldıkları için sahip oldukları kayıklar ile bu işe başvurduklarını söylemişlerdir. ${ }^{11}$ Kaçakçılık yapan kayıkçıların ifadelerine göre, yeterli miktarda ziraat ile uğraşabileceği toprağının olmaması, coğrafyadan dolayı ekim yapılabilen arazinin az olması, yüksek tonajlı buharlı gemilere karşı rekabet gücünün azlığı gibi nedenlerle kayıkçılardan en azından bazılarının kaçakçılık faaliyetlerine giriştiklerini tespit edebiliyoruz.

Trabzon Vilayeti'nde yetiştirilen ürünlerin kaçakçılığı yapılmaktaydı. Bununla beraber hem İran transit ticareti vasıtasıyla hem de Anadolu'nun Karadeniz'e çıkış limanları olmasından dolayı Trabzon Vilayeti'ne gelen ürünlerde de kaçakçılık yapılmıştır. Böylece bu vilayet pek çok emtianın yasadışı faaliyetlerde kullanılmasına sahne olmuştur. Bu emtiaların bazıları; findık, eşya, yolcu ve mektuptur. Fındık ile ilgili Trabzon Vilayeti'nin Dâhiliye Nezareti'ne gönderilen bir belgede ${ }^{12}$ Ordu, Giresun ve civarında yetişen findığın Rusya'ya kaçırıldığı bunun men edilmesi için ya findık ihracatının serbest bırakılması veya denizden motorla takip edilmesi hususunu içeriyordu. Başka bir belgede ise eşya ve yolcu kaçakçıllğı̆ndan bahsediliyordu. Belgeye göre, Rusya'dan Osmanlı memleketlerine gelen yelkenler ile kaçak yolcu ve eşya taşındığından bunların engellenmesi için Trabzon Vilayetince ihtiyaç duyulan gözetleme sandalları ile vapurların merkezden bir an önce gönderilmesi isteniyordu. ${ }^{13}$ Kaçakçıllı̆ 1 konu edinen başka bir belgede ise mektup kaçakçılığından bahsedilmekteydi. Vilayetler dâhilinde karayoluyla dağıtılan mektup ücretinin deniz yoluyla dağıtım ücretinden fazla olması mektup kaçakçılığına sebep olduğundan durumun düzeltilmesi ve gerekli önlemlerin alınması istenmiştir. ${ }^{14}$ Trabzon Vilayeti'nde kaçakçılığı yapılan bu kaçakçılık türlerinden başka vilayet dâhili için önemli sorunlara yol açmış kaçakçılık türlerini daha detaylı olarak aşağıda inceleyeceğiz.

\section{Tütün Kaçakçılığı}

XIX. yüzyılda tütün Trabzon Vilayeti dâhilinde en çok sorun çıkaran ve kaçakçılığı yapılan bir meta olarak karşımıza çıkmaktadır. Bu metanın XVII. ve XVIII. yüzyıllarda da kaçakçılığı yapılmaktaydı fakat XIX. yüzyıl ile kıyaslandığında bu durum hem kısıtlıydı hem de devletin

\footnotetext{
${ }^{8}$ BOA, Y..PRK.BŞK, 34/69, 28/C/1311. (H).

${ }^{9}$ BOA, DH.EUM. 6.Şb 3/38, 04/B/1333. (H).

${ }^{10}$ BOA, HR.TH. 31/23, 12/Ca/1879. (H). Rüsumat Emaneti İdaresi'nin, Fransız tüccar Giovanni'nin gümrükte el konulan kaçak tütünlerinden dolayı kendisine kesilen para cezasının ödenmesi talebinin sonuçsuz kalması üzerine Fransız Sefaretine çekilen nota.

${ }^{11}$ BOA, İ.ŞD. 17/728,22/Kânun-1 evvel/ 1317.

${ }^{12}$ BOA, DH.İ.UM. 20/2, 4/M/1337.(H).

${ }^{13}$ BOA, DH.TMIK.M. 240/28, 20/S/1325.(H).

${ }^{14}$ BOA, DH.MKT. 1019/16, 3/Ş/1323. (H).
} 
uyguladığ1 vergi sistemlerinden kaynaklanıyordu. Devlet uygulamış olduğu vergi ve gümrük uygulamaların $1^{15}$ indirime tabii tuttuğu an kaçakçılıkta azalma meydana geliyordu. Kaçakçılığı azaltan başka bir durum ise piyasadaki tütün talebinin karşılanabilmesi için üreticinin izin almadan tütün üretimini gerçekleştirebilmesidir. ${ }^{16}$ Böylece tütün ekimi ve gümrük vergileri serbest bırakılarak tütün kaçakçılı̆̆ 1 engellenmeye çalışılmıştır. ${ }^{17}$ XIX. yüzyılda tütün metasının Reji Şirketi'ne intikalinden sonra oluşan olumsuz hava ve Reji Şirketi'nin gerek güvenlik gerekse ekonomik yaptırım ve uygulamaları neticesinde tütün kaçakçılığında bir artış olmuştur. $\mathrm{Bu}$ artışa sebep olan durumlar ise; şirketin tütün deposu inşa etmemesi, kendi inşa etmediği depolara üreticinin tütününü nakil edememesinden dolayı üreticiyi kaçakçı olarak görme eğilimi ${ }^{18}$ tütün ekimi için kullanılan ruhsatların Reji tarafından her üreticiye verilmemesi, ${ }^{19}$ Reji tarafindan üreticiye düşük fiyat verilerek tütününü bu şekilde almak istemesinden kaynaklanıyordu. ${ }^{20}$ Bütün bunların sonucunda üreticinin zarara uğramasına neden olarak kaçakçılığın artmasına sebep oluyordu. ${ }^{21}$

Trabzon Vilâyeti tütün üretimi konusunda diğer vilâyetlere nispeten öncü vazifesini görüyordu. Ancak üretimin yaygınlığı oranında kaçakçılıkta fazlaydı. 1879 tarihinde Trabzon Vilâyeti'nde üretilen tütün miktarı aşağıdaki gibidir.

Tablo 1: 1879 Tarihinde Trabzon Vilâyeti'nde Üretilen Tütün Miktarı

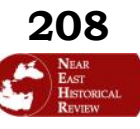

$10 / 2$

April

2020

\begin{tabular}{|l|l|l|}
\hline \multicolumn{1}{|l|}{1879 Tarihinde Trabzon Vilâyeti'nde Üretilen Tütün Miktarı Kıyye ${ }^{22}$ Cinsinden $^{\mathbf{2 3}}$} \\
\hline \multirow{5}{*}{ Trabzon Merkez } & Trabzon & 72.408 \\
\cline { 2 - 3 } & Akçaabat & 654.912 \\
\cline { 2 - 3 } Sancağı & Yomra & 18.811 \\
\cline { 2 - 3 } & Maçka & 4.320 \\
\cline { 2 - 3 } & Şarlı & 1.542 \\
\cline { 2 - 3 } & Tonya & - \\
\cline { 2 - 3 } & Vakfıkebir & 155 \\
\cline { 2 - 3 } & Görele & 35 \\
\cline { 2 - 3 } & Tirebolu & 4222 \\
\hline
\end{tabular}

\footnotetext{
${ }^{15}$ Fehmi Yılmaz, “Tütün”, Türkiye Diyanet Vakfi İslam Ansiklopedisi, XLII, Türkiye Diyanet Vakfi, Ankara 2012, s. 3.

${ }^{16}$ Emin Kırkbıyık; Mazide Kalan Reji, Samsun Eğitim Derneği Yayınları, Samsun 2013, s.8.

${ }^{17}$ BOA, Y.PRK.ML. 15/65, 29/Ş/1312.(H).

${ }^{18}$ BOA, DH.MKT. 1536/82, 20/Z/1305.(H) Reji anbarlarınca bir sene içinde anbarlara teslim edilmeyen tütünlerin kaçak sayılması, Reji İdaresinin tütünleri satın almadığının ve ziraatçinin mağdur edildiğinin beyanıyla anbarlara teslim olunacak tütünlerin satın alınmasının talep edildiği.

${ }^{19}$ Reji Şirketinin tarif ettiği ve nitelediği kaçakçı gruplarının arasında köylü yani üretici unsurlarda vardı. Bağında, bahçesinde kendi tüketimi için ruhsat almadan ektiği tütün için üretici kaçakçı sayılıyordu.

${ }^{20}$ BOA, DH.MKT. 2727/20, 10/01/1327. (H). Kaçakçılığın yaygınlaşmasının, Reji İdaresi'nce zürradan mübayaa olunan tütünlere düşük fiyat verilmesinden kaynaklandığına dair Trabzon Vilayetine gelen evrak.

${ }^{21}$ Nuray E.Keskin ve Melda Yaman, Türkiye'de Tütün: Reji'den Tekel'e Tekel'den Bugüne, Notabene Yayınlar1, Ankara 2013. s. 170.

221 Kiyye 1286 gramdir.

${ }^{23}$ TSV, 1879 , s. $154-155$.
} 


\begin{tabular}{|l|l|l|}
\hline \multirow{4}{*}{} & Ordu & 3194 \\
\cline { 2 - 3 } & Perşembe & 610 \\
\cline { 2 - 3 } & Bolaman & - \\
\cline { 2 - 3 } & Ulubey & 467 \\
\cline { 2 - 3 } & Hapsemana & 135 \\
\cline { 2 - 3 } & Aybastı & 1565 \\
\hline & Sürmene & - \\
\hline & Of & - \\
\hline & Rize & - \\
\hline Karadere & - \\
\hline Kuzistan Merkez Sancağı & - \\
\hline & Kurayıseba & - \\
\hline & Mapavri & 2.300 .000 \\
\hline Canik Merkez Sancağı & 320 \\
\hline
\end{tabular}

Üretilen tütün miktarı; bölge, toprak cinsi, kullanılan yöntem gibi faktörlerle değişkenlik gösterse de Rejinin ekim alanlarına müdahalesi, kaçakçılık gibi unsurlarda tütünün üretim miktarlarını etkilemiş azalmasına veya artmasına neden olmuştur. Aşağıda vereceğimiz tablolarda üretim miktarının nerelere dağıldığı tespit edilerek bu dağglımın dışında kalan tütünün kaçakçılık ile münasebeti ifade edilmeye çalışılacaktır.

Tablo 2: 1898-1899 Tarihlerinde Trabzon Vilâyeti Dâhilinde Üretilen ve Kullanılan Tütün Miktarları

\begin{tabular}{|l|l|l|l|}
\hline $\begin{array}{l}\text { 1898-1899 Tarihlerinde Trabzon Vilâyeti Dâhilinde Üretilen ve Kullanılan Tütün Miktarlarının Kilo } \\
\text { Cinsinden Değerleri }\end{array}$ \\
\hline & $\begin{array}{l}\text { Harice Sevk Edilmek } \\
\text { Üzere } \\
\text { Tarafından Satın Alınan } \\
\text { Tütün }\end{array}$ & $\begin{array}{l}\text { Reji Tarafından Satın } \\
\text { Alınan Tütün }\end{array}$ & Üretilen Tütün \\
\hline Trabzon Kazası & 155.017 & 307.087 & 491.975 \\
\hline Akçaabat Kazası & 1.326 .570 & 308.357 & 2.193 .027 \\
\hline Samsun Kazası & 1.252 .462 & 536.647 & 1.827 .350 \\
\hline Bafra Kazası & 2.250 .284 & 993.798 & 3.272 .577 \\
\hline Toplam & 4.984 .333 & 2.145 .889 & 7.784 .929 \\
\hline
\end{tabular}

\footnotetext{
${ }^{24}$ TSV, 1902, s.343.
} 
1898-1899 tarihlerinde Trabzon Kazası'nda üretilen tütün miktarı ile Reji Şirketi tarafindan satın alınan ve harice sevk için tüccar tarafından satın alınan tütün miktarları arasında 29.871 kilo fark vardır. Bu fark Akçaabat Kazası için 558.100 kilo, Samsun Kazası için 38.241 kilo, Bafra Kazası için ise 88.495 kilodur. Anlaşılacağı üzere harice sevk için tüccar tarafından satın alınan tütün, Reji Şirketi tarafından satın alınandan daha fazladır. Bu durum daha tütün tarlada iken tüccar-üretici ilişkisiyle kaçakçılığa dönüşebiliyordu. Tabloya göre toplam 654.707 kilo tütün kayıt dışıdır. Bu fark ya depolarda yüksek fiyatlandırma yapmak için bekletilen ya da depolara düşük kalitede ulaştığı için imha edilen ya da kaçakçılığı yapılan tütünlerdi.

Tablo 3: 1899-1900 Tarihlerinde Trabzon Vilâyeti Dâhilinde Üretilen ve Kullanılan Tütün Miktarları

\begin{tabular}{|c|c|c|c|c|c|}
\hline \multicolumn{1}{|c|}{$\mathbf{1 8 9 9 - 1 9 0 0}$ Tarihlerinde Trabzon Vilâyeti Dâhilinde Üretilen ve Kullanılan Tütün Miktarlarının Kilo Cinsinden } \\
Değerleri'
\end{tabular}

1899-1900 tarihlerinde Trabzon Kazası'nda 1 kilo tütün kaçırılmış ya da ürün fire vermiş olabilir. Akçaabat ve Bafra Kazaları ve Alaçam Nahiyesindeki tütün üretimi ve kullanılan tütün miktarları birbirleriyle uyuşmaktadır. Samsun ve Çarşamba Kazaları'nda kullanılan tütün miktarları tütün üretiminden 5 kilo fazladır. Bu durum önceki yıllardaki depolarda kalan tütün miktarı ile açıklanabilir. Ancak söz konusu salnamede harice sevk edilen toplam tütün miktarı ile toplam üretilen tütün miktarlarında sayısal bir yanlışlık yapılmış ve bu toplamda tarafımızca tespit edilip düzeltilmiştir. Bu durumda dahi kullanılan tütün miktarı toplam üretim miktarından 871 kilo fazla çıkmıştır. Bu ise önceki yıllardaki depolamayla alakadar olabilir.

\footnotetext{
${ }^{25}$ TSV, 1903, s.479.
} 
Tablo 4: 1901-1902 Tarihlerinde Trabzon Sancağı Dâhilinde Üretilen ve Kullanılan Tütün Miktarları

\begin{tabular}{|c|c|c|c|c|}
\hline \multicolumn{5}{|c|}{$\begin{array}{l}\text { 1901-1902 Tarihlerinde Trabzon Sancağı Dâhilinde Üretilen ve Kullanılan Tütün Miktarlarının Kilo Cinsinden } \\
\text { Değerleri }^{26}\end{array}$} \\
\hline Yer İsimleri & $\begin{array}{l}\text { Reji Ambarında } \\
\text { Mevcut, Üreticinin } \\
\text { Zimmetinde } \\
\text { Bulunan Tütün }\end{array}$ & $\begin{array}{lr}\text { Harice } & \text { Sevk } \\
\text { Edilmek } & \text { Üzere } \\
\text { Tüccar Tarafından } \\
\text { Satın Alınan Tütün }\end{array}$ & $\begin{array}{l}\text { Reji Tarafından } \\
\text { Satın Alınan Tütün }\end{array}$ & Üretilen Tütün \\
\hline Trabzon & 30.300 & 301.940 & 204.140 & 571.315 \\
\hline Akçaabat & 302.900 & 1.437 .240 & 491.605 & 2.408 .740 \\
\hline Giresun & 31.066 & - & - & 31.066 \\
\hline Ordu & 25.202 & - & - & 35.202 \\
\hline Sürmene & 8.350 & - & - & 8.350 \\
\hline Rize & 479 & - & - & 479 \\
\hline Toplam & 398.297 & 1.739 .180 & 695.745 & 3.055 .152 \\
\hline
\end{tabular}

1901-1902 tarihlerinde Giresun, Sürmene ve Rize yerleşim yerlerinde tütün üretimi ve kullanılan tütün miktarları birbirleriyle uyuşmaktadır. Ordu yerleşkesinde 10 bin kilo tütün kayıt dış1 olup kaçakçılıkta kullanılmış olabilir. Trabzon'da 34.935 kilo, Akçaabat'ta 176.995 kilo tütün kayıt dışıdır. Ayrıca söz konusu salnamede Reji ambarında mevcut, üreticinin zimmetinde bulunan tütünün toplam tütün miktarı ile Reji tarafından satın alınan tütünün toplam miktarlarında, üretilen tütünün toplam hesaplanmasına göre sayısal bir yanlışlık yapılmış ve bu toplamda tarafımızca düzeltilmiştir. Buna göre toplam 211.930 kilo kayıt dışı tütün tespit edilmiştir.

Tablo 5:Satın Alınan, Müsadere Olunan ve İhraç Edilen Tütün Miktarı

\begin{tabular}{|l|l|l|l|l|}
\hline \multicolumn{5}{|c|}{ Kilo Cinsinden ${ }^{27}$} \\
\hline Yıllar & Toplam & $\begin{array}{l}\text { Çiftçiden Satın } \\
\text { Alınan Tütün }\end{array}$ & $\begin{array}{l}\text { Kaçakçılar Yedinde } \\
\text { Müsadere Olunan } \\
\text { Tütün }\end{array}$ & $\begin{array}{l}\text { Ülke Dışına İhraç } \\
\text { Olunan Tütün }\end{array}$ \\
\hline $\mathbf{1 8 8 4}$ & 9.920 .240 & 9.920 .240 & - & 56.820 \\
\hline $\mathbf{1 8 8 5}$ & 10.350 .953 & 10.110 .453 & 240.500 & 909.107 \\
\hline $\mathbf{1 8 8 6}$ & 8.557 .790 & 8.238 .979 & 318.811 & 847.219 \\
\hline $\mathbf{1 8 8 7}$ & 10.222 .946 & 9.896 .785 & 326.161 & 999.752 \\
\hline $\mathbf{1 8 8 8}$ & 7.602 .419 & 7.333 .011 & 269.408 & 1.242 .701 \\
\hline $\mathbf{1 8 8 9}$ & 8.081 .603 & 7.781 .663 & 299.9440 & 2.200 .152 \\
\hline $\mathbf{1 8 9 0}$ & 7.829 .236 & 7.542 .291 & 286.945 & 1.690 .147 \\
\hline
\end{tabular}

${ }^{26}$ TSV, 1904, s.436.

${ }^{27}$ Tevfik Güran, 19. Yüzyılda Osmanlı Ekonomisi Üzerine Araştırmalar, Türkiye İş Bankası Kültür Yayınları, İstanbul 2014, s. 255. 


\begin{tabular}{|l|l|l|l|l|}
\hline $\mathbf{1 8 9 1}$ & 9.570 .729 & 9.300 .547 & 270.182 & 1.258 .660 \\
\hline $\mathbf{1 8 9 2}$ & 12.499 .908 & 12.319 .499 & 180.409 & 1.951 .839 \\
\hline $\mathbf{1 8 9 3}$ & 9.888 .594 & 9.708 .877 & 179.717 & 1.648 .333 \\
\hline $\mathbf{1 8 9 4}$ & 10.615 .021 & 10.336 .080 & 278.941 & 1.108 .768 \\
\hline $\mathbf{1 8 9 5}$ & 9.380 .772 & 9.028 .695 & 352.077 & 2.203 .630 \\
\hline $\mathbf{1 8 9 6}$ & 13.977 .415 & 13.407 .750 & 569.665 & 2.720 .350 \\
\hline
\end{tabular}

Tablo 6: Tütün Kaçakçıllı̆ 1

\begin{tabular}{|c|c|}
\hline \multicolumn{2}{|c|}{ Tütün Kaçakçılı̆̆ İstatistiğ ${ }^{28}$} \\
\hline Yıllar & $\begin{array}{c}\text { Yakalanan Kaçak Tütünüm Kilogram Cinsinden } \\
\text { Değeri }\end{array}$ \\
\hline $\mathbf{1 8 9 6}$ & 259.000 \\
\hline $\mathbf{1 8 9 7}$ & 314.000 \\
\hline $\mathbf{1 8 9 8}$ & 238.000 \\
\hline $\mathbf{1 8 9 9}$ & 197.000 \\
\hline $\mathbf{1 9 0 0}$ & 211.000 \\
\hline $\mathbf{1 9 0 1}$ & 233.000 \\
\hline $\mathbf{1 9 0 2}$ & 234.000 \\
\hline $\mathbf{1 9 0 3}$ & 212.000 \\
\hline $\mathbf{1 9 0 4}$ & 232.000 \\
\hline $\mathbf{1 9 0 5}$ & 189.000 \\
\hline $\mathbf{1 9 0 6}$ & 203.000 \\
\hline $\mathbf{1 9 0 7}$ & 221.000 \\
\hline Toplam & 2.743 .000 \\
\hline & \\
\hline
\end{tabular}

Tütün kaçakçılığına dair bu rakamlar XIX. yüzyılda Trabzon Vilayeti'nde kaçakçılık yapıldığı hakkında bilgiler vermektedir. Bununla beraber tütün kaçakçılığı noktasında arşiv belgelerinin varlığı bu vilayette tütün kaçakçılığının ${ }^{29}$ olduğuna kanıt niteliğindedir.

${ }^{28}$ Donald Quataert, Osmanlı Devleti'nde Avrupa İktisadi Yayılımı ve Direniş 1881-1908, Sabri Tekay (çev.), İletişim Yayınları, İstanbul 2017, s.49.

${ }^{29}$ BOA, BEO, 296/22144, 8/R/1311.(H).Akçaabad kaçakçılarından bazılarının silahlı olarak Gümüşhane yoluyla Bayburd üzerine hareket ettiklerinin haber alındığı ve vilayetin zaptiye ve kolcuları da yeterli olmadığından devletçe tedbir alınması; BOA, DH.ŞFR. 228/114, 22/Teşrin-i evvel/1314. Martini silahları taşıyan şahısların Hıristiyan köylerinde tütün satmaları, adam darp etmeleri ve sair kanunsuzluklarının önlenmesi gerektĭği. 


\section{Tuz Kaçakçılığı}

Tuz, insanoğlunun yaşamsal bir besin maddesi olmakla birlikte ekonomi, sanayi ve kültürel alanlarda ${ }^{30}$ da karşımıza çıkmaktadır. Tuz, besinlerin bozulmalarını önleyerek uzun vadede tüketilmelerinin sağlanması, derilerin tabaklanması, ${ }^{31}$ hayvancılık ve tarımsal faaliyetler, madencilik gibi çoğu alana katkı sağlamakta ve gelişmelerin bir parçası olmaya devam etmektedir.

Klasik dönem Osmanlı İmparatorluğu'nda tuz, devlet kontrolünde işlevsellik kazanmakta, üretiminden başlayarak nakliyesine, depolanmasına, pazarlanmasına, fiyat belirlenmesine kadar bütün işlerde devlet inhisarı/tekeli vücut bulmaktaydı. Her ne kadar tuzlalar devlet tekelinde bulunsa da işletilmesi dört ayrı şekilde meydana gelmekteydi. Birincisi iltizam yolu ile işletilmesi, ikincisi devletin kendisinin işletmesi, üçüncüsü tuz yataklarını keşfedenlere verilen işletme hakkı ve son olarak da aşiret beyleri veya tekke ve zaviyelere verilen işletme hakkı idi. ${ }^{32}$ Tuzlalar devlet tarafından işletildiği zamanlarda çeşitli şekillerde idare edilmişlerdir. ${ }^{33}$ Tanzimat Döneminde devlet, tuzlalardaki gelirleri arttırabilmek kendi yükünü hafifletmek ve sorumluluğu alıcılara yükleyerek oluşacak zararları minimuma indirgemek için 1857 tarihinde tuz tekelini Tırgıroğlu Dimitraki başkanlığında Bezirgân Zarifi adlı kişinin kefil olması ile bir şirkete 10 yıllığına devretmiştir. ${ }^{34}$ Ancak istenilen sonuç elde edilemeyince Bezirgân Zarifi Kumpanyasına ihale edilen tuzlalara dair anlaşma feshedildi. ${ }^{35}$ Fesih sonucu tuz tekeli, devlet tarafindan işletilmesi için Rüsumat Emanetine verilmiştir. ${ }^{36}$ Böylece önceden iltizam ve emanet usulü işletilen miri ve vakıf tuzlaları mültezim ve eminlerden geri alınmıştır. Şahıslar tarafından işletilen tuzlalar ise bedeli karşılığında satın alınmış ve devlet tekeli yeniden başlamıştır. ${ }^{37}$ İnhisar/tekelin uygulanması, hangi kuruma bağlı olacağı, yasaklamalar, ruhsatnameler, tuzun ticareti ve vergilendirilmesi, tuz kaçakçılı̆̆ gibi hususları belirlemek ve önlemler almak adına 1862 tarihinde "Tuz Nizamnamesi" yayımland $1 .{ }^{38}$

Nizamname öncesinde tuza dair uygulamalardan bir tanesinde belirli bir yerde üretilen tuzun, merkezi hükümetin izni ve bölge tarafından ihtiyaç hâsıl olmadığı sürece başka bir bölgeye nakledilmesi yasaklanmıştı. Ayrıca belirli bir tuzlada veya iskelede tuz satın alan tüccarlar o bölgede tuz satışını gerçekleştirebiliyorlardı. Başka bir bölgeye gitmek ve burada tuz satışı gerçekleştirmek kaçakçılık olarak kabul edilip şahısların ellerindeki tuza, hayvanlarına el konularak çeşitli cezalar veriliyordu. ${ }^{39} 1862$ tarihli nizamname yayımlandıktan sonra tuz yasakları ile ilgili olarak herkes satın aldığı tuzu istediği şekilde, istediği yer ve bölgeye nakledip serbestçe

\footnotetext{
30 Alper Gölbaş ve Zeynel Başıüyük, “Anadolu Kültür Oluşumunda Tuzun Rolü”, Batman Üniversitesi Yaşam Bilimleri Dergisi, 1/1, 2012, s.49.

${ }^{31}$ Ahmet Saim Arıkan; “Türk Deri İşlemeciliği Bağlamında Türk Cild Sanatı”, Uluslararası Asya ve Afrika Çalışmaları Kongresi, C.I, 2008, s. 124.

${ }^{32}$ Fatma Doğruel, ve Suut, Doğruel, Osmanlıdan Günümüze Tütün, Tekel/Tütün Vakfi, İstanbul 2000, s.112.

33 Örnek olarak Erzurum tuzlaları gösterilebilir çünkü bu tuzlaların idare şekilleri tuzlaların yönetiminin değişmesine paralellik göstermektedir. Buradaki tuzlalar mukataa olup has, ocaklık, iltizam, emanet, malikâne gibi yönetim süreçlerine sahne olmuştur. Neşe Erim; "18. Yüzyılda Erzurum Tuzlaları”, Tuz Kitabı, Emine Gürsoy Naskali, Mesut Şen (der.), Kitabevi, İstanbul 2004, s.246. ss. 241-247.

${ }^{34}$ Doğruel, Osmanlıdan Günümüze Tütün, s. 113.

${ }^{35}$ BOA, A. \}MKT.MVL. 118/99, 20/M/1277.(H).

36 BOA, A.\}MKT.NZD. 418/57, 15/N/1278.(H). Memleha, tuzla, tuz kuyularının inhisar/tekel olarak emaneten idaresine dair.

${ }^{37}$ Ekin Kasım, “1862 Tuz Nizamnamesi ve Önemi”, Gazi Üniversitesi Sosyal Bilimler Dergisi, 3/7, 2016, s.7.

${ }^{38}$ BOA, HR.ID, 308/4, 27-01-1862.(H).

${ }^{39}$ Gayr-i yerden getürmüş olanlar ise tuzların ve beygirlerin elinden ala, kendünün sakalını kese, burnuna kıl daka. Lütfi Güçer, "XV-XVII. Asırlarda Osmanlı İmparatorluğunda Tuz İnhisarı ve Tuzlaların İşletme Nizamı" İstanbul Üniversitesi Iktisad Fakültesi Mecmuast, 23/1-2, 1963, s. 125'den naklen Halil İnalc1k ve Robert Anheger, Kânûnnâme-i Sultanî BerMûceb-i Örf-i Osmanî, Türk Tarih Kurumu, Ankara 1956, s.29.
} 


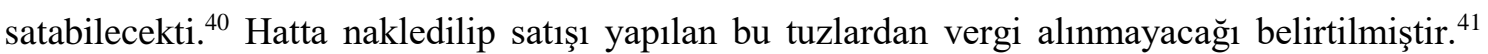
Ayrıca devlet, sadece toptan tuz alımına izin vermektedir. Önceden uygulanan ve reayanın menfaatine olan vadeli tuz satışı iptal edilerek nakit para ile alım-satımların gerçekleştirilmesi usulü getirilmektedir. Bu uygulama ise, reayanın şikâyetlerine konu olmuştur ve reayayı vadeli tuz satan kaçakçılara yönlendirmiştir. ${ }^{42}$ Ayrıca kaçakçılarla ilgili olarak tuz ithali yasak olduğu halde yabancı ülke gemilerinden karaya çıkarılmak üzere sandal ve kayıklara yüklenen tuzlara el konulması tedbiri getirilmiştir. ${ }^{43}$ Tuz kaçakçılığı için ruhsatsız olarak yurda sokulan tuzlarla, kendi tarlasında veya arazi-i miriye de tuz ocağı işletenlerden alınacak para cezasını düzenlemek üzere, "Tuz Nizamnamesine" ek madde eklenmesi uygun bulunmuştur. ${ }^{44}$

Tuza dair devlet inhisar1/tekeli devam ederken Osmanlı Devleti'nin, Galata bankerlerinden almış olduğu iç borçları nedeniyle, bir ödeme planı oluşturuldu. Buna göre, Rusüm-1 Sitte denilen altı vergi kalemi Galata bankerlerin işletmesine verildi. Bu kalemlerden biri de tuz idi. Başarılı olan bu plan Avrupa devletlerinin dikkatini çekerek Osmanlı dış borçlarının da bu tür vergi kalemleri vasıtasıyla ödenebileceği fikrini ortaya çıkarmıştır. Osmanlı Devleti'nin borçlarını ödeyemeyeceğini ilan etmesi üzerine Avrupa devletleri temsilcileri vasitasiyla Duyun-1 Umumiye/borçlar idaresi kurulmuştur. Buna göre tuz gibi pek çok vergi kalemi bu idareye devredilmiştir. Böylece diğer kalemler gibi tuz konusunda da yeni bir düzen ve işleyiş meydana gelmiştir.

Tuz kaçakçılığında alınacak tedbirler hususunda Duyun-1 Umumiye, Osmanlı Hükümeti’ni saf dışı bırakarak kendisinin tek yetkili olmasını arzu ediyordu. Bu sayede kaçakçılığı önleme konusunda tütün Rejisi ve Osmanlı Hükümeti arasında yaşanan anlaşmazlıklara düşmeyerek kendisi çözüm üretecekti. 2 Mayıs 1885 tarihinde Şura-yı Devlet'in vermiş olduğu karar ile tuz kaçakçılığını önleme ve takip etme işi idareye verilmiştir. ${ }^{45}$ Duyun-1 Umumiye kaçakçılık ile ilgili bir takım tedbirler almıştır. Öncelikle ruhsat ve tezkere konusunda titiz davranarak bu konuda hataya mahal vermemeye çalışmıştır. Tezkerede tuzu alan şahsin kimlik bilgileri, tuzun miktarı ve tuzu nereden alıp nereye götürüleceği açıkça işlenmiş olup eğer yanlış bir bilgi içeriyorsa tezkerede bir düzeltme veya silme meydana gelmiş ise kaydı tutan memur görevden alınıyordu. ${ }^{46}$ Duyun-1 Umumiye, hükümet ile işbirliğine giderek tuz kaçakçıllğını kontrol altında tutmaya çalışıyor. ${ }^{47}$ alınan diğer tedbirlerle kaçakçıları yapmış oldukları fillerden vazgeçirmeği hedefliyorlardı. Bu bakımdan tuz kaçakçılarının mevcut tuz fiyatının iki katı para cezası kesilmektedir. Bu para cezası karşılanmadığı takdirde ise bir günden üç aya kadar hapis cezası olarak cezalandırılmaları gerekmekteydi. ${ }^{48} \mathrm{Ne}$ var ki bu pek mümkün olmamaktadır. Tuz kaçakçılarının yargılandığı çoğu dava ya para cezası ile ya da beraat ile sonuçlanmıştır. ${ }^{49}$ Diğer kaçakçılık türlerinde olduğu gibi tuz kaçakçılığında da bu işi yapanlar ulaşımın, haberleşmenin

\footnotetext{
${ }^{40}$ Kasım, "1862 Tuz Nizamnamesi ve Önemi”, s.9.

${ }^{41}$ BOA, DH.MKT. 67/31, 19/Z/1312.(H).

${ }^{42}$ Kasım, "1862 Tuz Nizamnamesi ve Önemi", s.8.

${ }^{43}$ BOA, A. \}MKT.MHM. 270/69, 04/S/1280.

${ }^{44}$ BOA, İ..DH. 1295/101725, 03/N/1286.(H).

${ }^{45}$ Resül Narin, “Düyûn-1 Umûmiye İdaresi ve Adapazarı”, Karadeniz Araştırmaları Dergisi, 6/21, 2009,ss.49-59. s.52.

${ }^{46}$ Kasım, "1862 Tuz Nizamnamesi ve Önemi" s.9-10.

47 BOA, ŞD. 7/10, 14/N/1306.(H). Tuz kaçakçılığının engellenmesi için Duyun-1 Umumiye İdaresi'nce İngiltere'den getirtilen vapura maaş vesair masrafları Duyun-1 Umumiye'den ödenmek üzere Tersane'den zabit ve asker verilmesi istenmiştir; BOA, Y..A...HUS. 276/12, 4/Z/1310. Bazı bölgelerde ki tuzlalardan yapılan kaçakçılığın önlenmesi için askeri müfreze görevlendirilmesi, askerlerin çadır yerine kışla ve koğuşlarda ikamet etmesi için doğacak olan masrafın Duyun-1 Umumiye İdaresince yapılmasının teklifine dair.

${ }^{48}$ Fatmagül Demirel, “Osmanlı Devleti'nde Tuz Gelirlerinin Düyûn-1 Umûmiye’ye Devredilmesinden Sonra Tuz Kaçakçılığı”, Tuz Kitabı, Emine Gürsoy Naskali, Mesut Şen (der.), Kitabevi, İstanbul 2004. s. 303.

${ }^{49}$ BOA, DH.ID.. 17/26, 22/R/1330.(H). Kaçak ecnebi tuzu satanlar hakkında açılan davanın beraatle neticelendiği; BOA, ŞD. 1848/36, 16/L/1313.(H). Ecnebi tuzu kaçakçılığından dolayı bidayeten ve istinafen cereyan eden muhakemesinde beraet etmiş olan Rizeli Torlak oğlu Hüseyin hakkında bir belge.
} 
ve yönetimin zayıf olduğu bölgeleri tercih ediyordu. Bu yüzden yerel yönetimler tuz kaçakçılı̆̆ının men edilmesi ve kaçakçıların yakalanması için haberleşme ağları kurmayı, yönetimlerinin askeri kuvvetlerle desteklenmesi için çalışmalar başlatmıştır. ${ }^{50}$

Trabzon Vilayeti dâhilinde XIX. yüzyılda hiçbir tuzlaya rastlanılmamıştır. Kullanılan tuzlar dışarıdan ithal edilmiş olup Duyun-1 Umumiye İdaresi vasıtasıyla satılmaktadır. ${ }^{51} \mathrm{Bu}$ nedenle dâhilde üretimden kaynaklı tuz kaçakçılığına rastlanmamıştır. Dışarıdan getirilen tuz üzerinde kaçakçılık yoğundur ve bu türlü yöntemlerle yapılmıştır. Yabancı bandıra kullanılarak yapılan tuz kaçakçılığında genellikle Laz kaçakçılar dikkat çekmiştir. ${ }^{52}$ Laz kaçakçılar yanında yabancı menşeli şahıslarda tuz kaçakçılığı yapmışlardır. ${ }^{53}$ Duyun-1 Umumiye İdaresi'nin Trabzon Vilayeti dâhilinde kaçakçılığa dair almış olduğu tedbirler çoğunlukla deniz vasıtalarıyla olmuştur. Çünkü tuz kaçakçıllğ yabancı memleketlerden gelen tuz ile yapılmaktaydı. ${ }^{54}$

Sonuç olarak, Osmanlı Devleti'nde tuzun işlevselliği, çeşitliliği fazla olmasına rağmen üretim miktarı ve tuzlaların varlığı her bölge ve mahal için aynı değildir. Ancak bu durum tuz kaçakçılığını olumsuz etkileyen bir unsur olmaktan uzaktır. Çünkü kaçakçılar şartlara uyum sağlayan ve bölgenin durumunu bilen nereden hangi vasıta ile tuzu kaçırabileceğini iyi analiz eden gruplardır. Tuz, önemli bir meta olmasından dolayı bu metanın kaçakçılığını belgelerle tespit edilebilmek mümkündür.

\section{Silah Kaçakçılığı}

Askeri mühimmat, silah, top, barut, güherçile ve türevleri olan kaçakçılıklar, diğer kaçakçıllğı yapılan, emtialardan farklı olarak şahısları ve devletleri ekonomik olarak güç kaybına uğratmanın yanı-sıra can ve mal kaybına neden olması, eşkıyalık hareketlerinde kullanılarak kaos ortamına sebebiyet vermesi, şiddetli yıkıcı ve yakıcı tahribatlara yol açarak nüfus hareketliliğine neden olması ve kitleleri bir imha gücüne dönüştürmesi hasebiyle bu kaçakçılık türü, engellenmesi elzem ve bir o kadarda zor bir vaka olarak yüzyıllardır devam edegelmiştir. Osmanlı Devleti'nin sınırlarının genişliği, pek çok limana sahip olması ve kıyı şeritlerinin fazlalığı silah kaçakçılığının farklı bölgelerde yapılma olanaklarını arttıran bir durum olmuştur. ${ }^{55}$ XVI. yüzyılın son çeyreğinde Karadeniz üzerinden Sukhumi Limanı vasıtasıyla yapılan ticaret kaçakçılığa dayanmaktaydı ${ }^{56}$ XVII. yüzyılda Kuzey Anadolu sahillerine Karadeniz'den Kazak saldırıları baş göstermişti. Osmanlı Devleti böyle zor zamanlarda bile silah kaçakçılığından endişe duyuyordu ve Sinop’ta

\footnotetext{
${ }^{50}$ BOA, MV. 54 158, 21/L/1307.(H). Kastamonu Vilayetindeki tuz kaçakçıllı̆ının engellemek ve kaçakçıların yakalanması için, telgraf hattının İnebolu'dan Cide'ye kadar kurulması ve mahalli zabtiye kuvvetlerinin arttırılması.

${ }^{51}$ TSV, 1894, s.115.

52 BOA, HR.HMŞ.IŞO. 70/30, 19/Kanun-1 Evvel/1325. Vapuruna izin almadan Rus bayrağ1 çeken ve tuz kaçakçıllğ 1 yapan Rizeli Ferhat hakkında gerekenin yapılması gerektiği.

${ }_{53}$ BOA, HR.TH. 250/6, Tarihsiz. Tuz kaçakçılı̆̆ yapan Alman vatandaşlarından Antuvan Parma'nın yargılanması.

${ }^{54}$ BOA, ŞD. 7/10, 14/N/1310.(H). Tuz ve tütün kaçakçıllı̆̆ının meni için Trabzon Vilayeti'nde müstahdem vapurlara ilave olarak, masarif-i daimeleri Rüsumat Emaneti ile Düyun-1 Umumiye ve Reji daireleri tarafından tesviye edilmek üzere iki vapur bulundurulması.

${ }^{55}$ Avusturya ve İtalya'da Arnavut kaçakçılarına silah verenler arasında aktif bir faaliyetin mevcut olduğu. Karadağ sahillerine giden vapurlarda muhtelif sandık eşyaları arasında barut taşındığının tespiti. Avrupa limanlarında çalışan Arnavut, Karadağ ve Yunanlı yelkenli gemilerin doğrudan ve Karadağ yoluyla Arnavutluk'a silah kaçakçılığı yaptıkları, buna karşı gerekli tedbirlerin alınması zarureti olduğu yönünde BOA, HR. SYS. 141/4, 6/Ra/1327.(H); İzmir Limanı'na gelen İtalyan gemisinde kaçak silah ve barutun bulunması_BOA, Y. PRK. ML. 15/43, 19/S/1312.(H);Anadolu'nun Akdeniz sahilindeki Teke, İçil ve Antalya kısımlarında silah ve yasak madde kaçakçılığının yapılması ve önlenmesine dair tedbirler DH. MKT. 36/9, 14/R/1312.(H). Yemen sahilleri ve Aden Limanı üzerinden yapılmakta olan silah kaçakçılığı hakkında A.\}MKT.MHM. 500/22, 22/Ca/1312.(H).

${ }^{56}$ Osmanlı Devleti, Abazalarla ve Mingrelistan ile yürütülen ticaret silah kaçakçılığına dayanmaktaydı. Bu nedenle Osmanlı Devleti Abazalarla olan ticarete yasak getirmiştir. Ancak bu durum kaçakçılığın azalmasına engel olamamış aksine artmasına olanak sağlamıştır. SuraıyaFaroqhı, Osmanlı'da Kentler ve Kentliler, Neyyir Kalaycıoğlu (çev.), Tarih Vakfi Yurt Yayınları, İstanbul 1994, s.108.
}

\section{5}

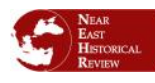


uygulamış olduğu yöntem, silah kaçakçılığından nasıl çekindiğini gözler önüne seriyordu. Sinop Kazak saldırılarından korunmak için yeterli silah ve top mühimmatından yoksundu ve merkezden bu ihtiyacının giderilmesini talep etmişti. Ancak payitaht bu talebi yerine getirememiştir. Bunun yerine Sinop'ta şayka adında küçük toplar dökülmesine izin vermiştir. Ancak toplar için kalıcı kârhâne ve ocaklar inşa edilmemesini, gemilere ve başka memleketlere top gönderilmemesini emretmiştir. Bu durum silah kaçakçılığını engellemeye yönelik tedbir olarak değerlendirilebilir. ${ }^{57}$

1524 tarihli Mısır Kanunnamesi, silah ile ilgili hükümleri olan ve silahla ilgili en eski yasakları barındıran bir kanunname idi. ${ }^{58}$ Ayrıca kanunnamede devlet görevlileri dışında silah taşımak, silah üretmek yasakt1. ${ }^{59}$ Ancak XVII. yüzyıl şer'iyye sicil defterlerinden tespit ettiğimize göre; tereke kayıtlarında birçok şahsın üzerinde silah mevcuttur. ${ }^{60} \mathrm{Bu}$ durum, eşkıya varlığından dolayı şahısların kendi can ve mal güvenliğini korumak istemelerinden ileri gelebileceği gibi muharip kuvvetlerin yetersizliğinden de olabilmekteydi. Fakat asıl dikkat edilecek nokta 1906 tarihli "Fabrikalar Nizamnamesi'nde" de belirtildiği gibi; "her türlü silah ve patlayıcı madde, barut, fişek ve türevleri devlet tekelindedir" șeklindeki hükmün uygulanmasıydı. ${ }^{61}$ Tespitimize göre, bu durum şahısların üzerindeki silahları kaçak yollarla temin ettikleri anlamına gelmektedir. ${ }^{62}$

Osmanlı Devleti'ndeki silah ve çeşitlerine dair yasaklanmış uygulamalar sadece reayanın üretim $^{63}$ ve taşımasına yönelik kısıtlamalar olmayıp silah ve türevleri devlet tekelinde bulunduğu için ticaret anlaşmalarıyla yabancı devletlere ve tüccarlara da bu kısıtlamalar uygulanmıştır. 1846 tarihinde Rusya ile Osmanlı Devleti arasında yapılan ticaret antlaşması ateşli silahlar ve barut gibi maddelerde Rusların esnaflık yapmaları yasaklanmış ve kısıtlamalar getirilmiştir. ${ }^{64} 29$ Nisan 1861 tarihinde Fransa ile imza edilen ticaret antlaşmasında da bu kısıtlamalar bulunmaktadır. ${ }^{65}$ Antlaşmanın onuncu ve on birinci maddeleri tütün, tuz, top, barut, esliha ve harb mühimmatlarının Osmanlı topraklarına ithalindeki yasaklamaları içeriyordu. ${ }^{66} 21$ Şubat 1872 tarihinde ilan edilen Barut Nizamname'nin on beşinci maddesinde de ister doğrudan isterse gizliden olarak Osmanlı memleketlerine ithal olunan yanıcı ve patlayıcı maddelere bedelsiz el konulacak ve müsadere edilecek, bedelinin iki misli para cezası olarak alınacakt1. ${ }^{67}$ Bütün bu yasaklamalara ek olarak

\footnotetext{
${ }^{57}$ M. Ali Ünal, “17. Yüzyılda Karadeniz'de Kazak Saldırıları ve Karadeniz Ticareti”, ' Tarih Boyunca Karadeniz, Ticareti ve Canik, Osman Köse (der.), Canik Belediyesi Kültür Yayınları, II, Samsun, 2013, s. 854.

${ }^{58}$ S. Hilmi Özkan, "Arms Smuggling Across Ottoman Borders in the Second Half of the 19th Century", Journal of Balkan and Near Eastern Studies, 18/3, 2016, s.302.

${ }^{59} \mathrm{Bu}$ yasaklar genişletilmiş biçimde 1907'de hala devam ediyordu. Silah taşımaya selahiyeti dışında bulunanlarla, çeşitli sebeplerle el konulacak silahlar ve evlerde bulundurulması yasak olan patlayıcı maddeler on beş maddelik bir nizamname ile tanzim edilmiştir. BOA, ZB. 360/30, 20/Haziran/1325.

${ }^{60}$ Musa Uzun, 1924/110 No'lu Trabzon Şer'iyye Sicil Defterinin Transkripsiyonu ve Tahlili, (Yayınlanmamış Yüksek Lisans Tezi), Ondokuz Mayıs Üniversitesi Sosyal Bilimler Enstitüsü, Samsun 2007, s. 44-45.

${ }^{61}$ Didem Boyacıoğlu, “Tanzimat'tan Cumhuriyet'e Osmanlı Fabrika Yapılarının İnşasına Dair Yapılan Düzenlemeler”, Uluslararası Sosyal Araştırmalar Dergisi, 8/38, 2015, s.478.

${ }^{62}$ Silah ve türevleri kaçakçılığı Karadeniz ve Trabzon Vilayeti cihetlerinde yaygındı. Bir belgede, kaçakçıların üzerinde yakalanan fişeklerin Barut Nizamnamesine göre para cezası ile cezalandırılmaları istenmektedir. BOA, ZB. 609/94, 15/Haziran/1323. Bir başka belgede ise Rize yolu ile Dersaadet'ten Trabzon'a gelen Hudeyde Vapuru yolcuları arasında bulunan üç kadının üzerinde silah ve cephane bulunmasıdır. Belgede kaçakçılık işine kadınlarında karıştığını, bu durum ise kaçakç1lıkta cinsiyetin önemsenmediğine işaret etmektedir. BOA, DH. MKT. 498/35, 29/M/ 1320.(H).

${ }^{63}$ Giresun'un Ayavasil Köyü’nde bazı Müslüman hanelerde martini ve tüfek imali, yabancı vapurlardan silah ve patlayıcı madde temin edilmesi. BOA, ZB. 615/59, 25/Ş/1323.(H).

${ }^{64}$ Muâhedât Mecmûası,, s.104-106.

${ }^{65}$ Necdet Kurdakul, "Ticaret Antlaşmaları", Tanzimat'tan Cumhuriyet'e Türkiye Ansiklopedisi, İletişim Yayınları, III, İstanbul 1985, s.666. ss.666-667.

${ }^{66}$ Muâhedât Mecmûast; s. 48-49.

67 Süleyman Uygun, "Paquet Vapur Nakliyat Kumpanyası (Compaignie De Navigation Paquet) Ve Osmanl1 Ermenileri”, A. U. Türkiyat Araştırmaları Enstitüsü Dergisi, s. 56, 2016, s. 1349.
} 
Osmanlı Devleti silah ve barut üretmeye yarayan malzemelerinde satışını zaman zaman yasaklamıştır. Bu tür yasaklamalar üretici ${ }^{68}$ ve tüccar ${ }^{69}$ açısından kaçakçılıkla sonuçlanmıştır.

Osmanlı Devleti'nde silah kaçakçılı̆̆ hem kara hem de deniz vasıtalarıyla yapılıyordu. Deniz vasıtalarıyla yapılan kaçakçılık karadan yapılan kaçakçılığa göre daha fazlaydı. Bunun nedeni XIX. yüzyılda buharlı gemi teknolojisinin gelişme göstermesi, gemi şirket ve kumpanyaların kurulması, ticaret anlaşmalarıyla Karadeniz'in kullanılabilirliğinin artması ve Osmanlı Devleti'nde yaşamalarına rağmen gemilerine başka devletlerin bandıralarını çekip ticarete yönelenlerin artış göstermesinden dolayı deniz yoluyla yapılan kaçakçılıkta bir yoğunluk oluşmaktaydı. Öncelikle belirtmek gerekir ki devlet denizden ${ }^{70}$ ve karadan $^{71}$ yapılan silah kaçakçılığını önlemek adına tedbirler almıştır. Yabancı devletlerin kurmuş olduğu kumpanyalar o kadar çok silah kaçakçılığ takip etmiştir. Örneğin; Avusturya Lloyd Kumpanyası'nın Helyos adlı vapuru içinde tüfekler ve fişekler zuhur ettiğinden bütün vapurların, özellikle Lloyd Kumpanyası'nın vapurları gözetim altında bulundurularak, silah kaçakçıllığının men edilmesi istenmiştir. ${ }^{72}$ Konuya dair başka bir belgede ise Rus sancağı taşıyan bazı küçük vapurların Batum, Hopa, Arhavi, Atina, Rize, Of ve Sürmene iskeleleri arasında seyr ü sefer yaparak pasaportsuz şahıslarla silah ve kaçak mal taşıdıkları bildirildiğinden, Trabzon ve Yalıköşkü vapurları tarafından aralıklı olarak sahillerin kontrol edilmesi istenmektedir. ${ }^{73}$ Hatta konsoloslukta çalışanların akrabaları da silah kaçaklığına yöneldikleri olmuştur. Rusya'dan, Rusya Trabzon Konsolosluğu Tercümanı Bedros'un biraderi Ohannes'in kaçak silah getirdiği ve bu durumun önlenmesine dair gerekenin yapılması istenmektedir. ${ }^{74}$ Bunun dışında elçilikler arasında da silah kaçakçılı̆̆ı mevzu bahis olmuş ve bu durum karşısında merkezi hükümet net tavır takınmıştır. Lloyd Kumpanyası'na ait anbardan bir sandala yüklenirken el konulan dört sandık silah ile kumpanyanın Selete adlı vapuruna aktarma yapılırken ele geçirilen tabancaların Avusturya Sefareti'ne iade edilmeyecektir. ${ }^{75}$ Kumpanya ve şirketlerin devlet tarafından sürekli takibatta bulunulması, ayrıca limanların yeterince derinlikte olmaması yüksek tonajlı buharlı gemilerin limanlara yaklaşımını sınırlandırıyordu. Bu yüzden iskele ve gemi arasında malların taşınması işini yapan kayıkçılara ihtiyaç duyuyordu. ${ }^{76}$ Ancak kayıkların liman haricindeki her kıyıya yanaşabilmesi ve yeni farklı bir geçim kaynağı oluşturma çabası içerisine girmesi ve denetimden biraz daha uzak olması kayıkçı taifesini de silah kaçakçıllığına yönlendirmiştir. ${ }^{77}$ Osmanlı Devleti'nde yaşanan silah kaçakçılığ 1 , bazen politik

\footnotetext{
${ }^{68}$ Güherçile barut yapımında kullanılan ana bileşenlerden biridir. Bu nedenle tek alıcı devlet olduğu için, güherçile satımı yasak metalardan da biriydi. Ancak devletin üreticiye piyasa fiyatının altında ücret vererek güherçileyi talep etmesi üreticiyi zor durumda bırakmış ve üreticiyi alternatif bir yol bulma çabasına itmiştir. Yunus İnce, Osmanlı Barut Üretim Teknolojisinde Modernleşme: Azadlu Baruthanesi (1794-1878), (Yayınlanmamış Doktora Tezi), Selçuk Üniversitesi Sosyal Bilimler Enstitüsü, Konya 2013, s.151; Ayrıca, üretici güherçileyi kârlı bir şekilde elinden çıkarmak için kaçakçılığa ve yabancı tüccara yönelmiştir. BOA, DH. MKT. 601/68, 23/B/1320.(H).

${ }^{69}$ Bakır, silah sanayisinde top ve tüfek yapımında, XVIII. Yüzyıl sonlarından itibaren de savaş gemilerini kaplamak için kullanıldığından bu madene duyulan ihtiyaç fazlaydı ve tüccarlar alıcılarına kaçakçılık yoluyla bu madeni sevk ediyorlard1. Mehmet Genç, "17.-19. Yüzyıllarda Sanayi ve Ticaret Merkezi Olarak Tokat”, Türk Tarihinde ve Kültüründe Tokat Sempozyumu, 1986, s.164.

${ }^{70}$ Denizden yapılan barut ithalinin engellenmesi için Trabzon ve Kastamonu Vilayetlerinin tedbir alması. BOA, DH.MKT. 1522/5, 7/Za/1305.(H).

${ }^{71}$ Rizeli kaçakçıların Of kazası yoluyla naklettikleri portakal sandıklarından silah ve mühimmat bulunmuştur. Bu gibi vakaların olmaması için merkez, gümrükten daha dikkatli olunması istenmiştir. BOA, DH. TMIK. M. 103/38, 14/M/1319.(H).

${ }^{72}$ BOA, ZB. 46/14, 8/Mayis/1324

${ }^{73}$ BOA, DH.TMIK.M. 139/37, 28/Za/1320.(H).

${ }^{74}$ BOA, Y.PRK.UM. 27/77, 22/Z/1310.(H).

75 BOA, A.) MKT.MHM, 500/22, 22/Ca/1307.(H).

${ }^{76}$ M.Yavuz Erler, “İstanbul'da Deniz Ulaşımı (1870-1875)", Osmanlı Araştırmaları, XXI, 2001, s.72.

77 BOA, DH.MKT. 2906/84, 5/Ş/1327. (H). Samsun'da silah kaçakçılığı yapan kayıkçı ve gümrük memurlarının bulunarak gerekli işlemlerin yapılması istenmektedir; BOA, DH.MKT. 966/40, 4/R/1323.(H). Osmanlı sahillerinden
} 
amaçlı yapılarak devletin dağılma ve parçalanmasında etkili olmuştur. Bazen de sadece esnaf ve tüccarın ekonomik gelirini arttırmak istemesinden kaynaklanmıştır. Silah kaçakçı1lı̆̆ nedeniyle merkezi hükümet ekstra maddiyat, zaman ve çaba sarf etmiştir. Fakat silah kaçakçılarıyla ilgili sert tedbir ve cezalar uygulanmadığı için silah kaçakçılığında azalma yerine artış meydana gelmiştir.

\section{Maden Kaçakçılığı}

Madenler, yeraltı zenginliği kadar bu zenginliğe hükmeden iktidarlar içinde her daim bir güç ve refah unsuru olmuştur. Madenler; yeniliğin, tekniğin, gelişmenin yanında devletleri rakiplerine karş1 zamanının ötesine götüren ana materyallerden biri olmuştur. Böylesine parasal değeri ve gücü olan madenlere devletler sahip olmak isteyerek maden ticaretinin güvenliğine bilhassa önem atfetmişlerdir. Bunun için çeşitli düzenlemeler, yasaklamalar, kanunlar ve cezai işlemler meydana getirmişlerdir. Bu tedbirleri alan ve uygulayan devletlerden bir tanesi de Osmanlı Devleti olmuştur.

Madenlerin belli zamanlarda ve belli hükümlerle ihracının yapılmasının yasaklanmasının yanında bu madenlerin işlenerek çeşitli mamul mâl haline getirilip satılması da yasaklanmıştır. Böylece yasak kapsamı geniş tutularak kaçakçılık faaliyetlerinin kontrol edilebileceği düşünülmüştür. Fakat bu yasak ve cezai işlemler her zaman uygulanamamıştır ve kaçakçılık faaliyetleri sürüp gitmiştir. Tarihi belirlenememiş bir belgede ahali, Gümüşhane kadısına bazı şahısların kazadaki madenden çıkarılan gümüş ve bakırı usulsüz olarak sattıklarını şikâyet etmektedir. ${ }^{78}$ Ayrıca, Osmanlı Devleti, Gümüşhane ve çevresinden Acem Ermeni, tüccarları vasıtasıyla altın ve gümüşün İran'a, Tiflis ve Halep taraflarına kaçırılmaması için güvenlik önlemleri almıştır. ${ }^{79}$ Ancak bu önlemler pek yaptırımı olmayan, suçu işleyeni caydırıcı yaptırımları bulunmayan önlemler olup, altın ve bakır kaçıranların ellerinde bulunan bu madenlerin vezin ile bedelinin ödenerek alınması veya başka bir altın ve zolata tabir edilen paralarla değiştirilmesi yoluna gidilmiştir. ${ }^{80}$ Bununla birlikte bu tedbirler her zaman yumuşak olmamış, kaçakçılık faaliyetlerine yönelik yaptırımlar zamanla ağırlaştırılmıştır. Canik Sancağ' 'ndaki bir maden kaçakçılığı olayı bunun iyi bir göstergesidir. 1762 tarihinde Erzurum, Sivas ve Canik'te müstahkem kuleleri bulunan ve emrinde sekiz yüz silahlı adamı olan Niksarlı Küçük Ali isimli bir eşkıya, Canik Sancağı'nda bir maden bulup işleterek, devletin paralarına benzer paralar imal ederek bu paraları Kırım üzerinden İstanbul'a sevk ederek piyasaya sürüyordu. Halkın şikâyet dilekçelerini değerlendiren devlet görevlileri tahkikat sonucunda durumun doğru olduğunu tespit etmişlerdir ve Niksarlı Küçük Ali uzun uğraşlar sonucunda yenilgiye uğratılıp öldürülmüştür. ${ }^{81} \mathrm{Bu}$ tür olayların önünü alabilmek için hükümet önceden gereken tedbirin alınması yoluna gitmiştir. ${ }^{82}$ Anlaşılacağı üzere devlete bildirilmeden yasadışı yapılan maden işletmeciliği ve kaçakçılığı iktidar tarafından sert tepkiyle karşılaşmıştır.

Maden kaçakçılığı ile ilgili yöntemler çeşitlilik arz etmektedir. XIX. yüzyılda sık sık karşımıza çıkan tür; altın, bakır, gümüş madenlerinin darphane yoluyla paraya dönüştürülüp hârice servis

\footnotetext{
Batum'a firari ve eşkıyaları taşıyan, silah kaçakçılığı yapan küçük kayıkların engellenmesi görevini kötüye kullanan liman reislerinin cezalandırılması istenmektedir.

${ }^{78}$ BOA, A. \{DVNS MHM.d. 101/263, Tarih yoktur.

${ }^{79}$ BOA, C.DRB. 36/1789, 12/Ra/1138.(H).

${ }^{80}$ BOA, C.DRB. 35/1739, 27/Za/1108.(H).

${ }^{81}$ M. Yavuz Erler ve Mucize Ünlü; "Refuges in The Basin of the Canik Mines: Greek Orthodox From Mining to Agriculture (1790-1884)", Black Sea History, 5, 2015, s.195.

${ }^{82}$ Şebinkarahisar'ın Kemin Beli mevkiindeki tarlasında bulduğu gümüş, bakır ve kurşun madenini işleten Atmaca'nın durumunun incelenmesi istenmiştir. BOA, A.\}MKT.MHM. 18/22, 22/Za/1265.(H).
} 
edilmesidir. ${ }^{83}$ Kaçakçılıkta diğer bir yöntem ise, paraların ayarını düşürmek sahte para basımı yapmak ve bunları yeni gelişen bankacılık sistemiyle aklayıp dâhile ve hârice çıkarmaktır. ${ }^{84}$ Para kaçakçılığı bazı zamanlarda devletleri de karşı karşıya getirmiştir. Osmanlı tebaası tüccar Hacı Kamil Efendi'nin, gemisinde kaçak Rus gümüş parası bulundurduğu gerekçesiyle Rus yetkililerin Koudago (Gudaba) limanında parası ve gemisine el konulmasıyla bu tüccar, Osmanlı Devletine şikâyette bulunmuştur. Osmanlı Devleti ise tüccarın uğramış olduğu zararın karşılanması için Rus yetkililerine başvurmuştur. ${ }^{85}$ Bir diğer maden kaçakçıllğ 1 türü ve yöntemi ise madeni ham materyal olarak değil de işlenmiş bir vaziyette kaçakçılığının yapılmasıdır. 1863 tarihinde Canik Sancağı'nda yapılan araştırmada Kürtün ve Karayaka oymağından gelen göçmenlerin maden cevheri kullandıkları ve demir cevheri kaçakçılığ yaptıkları belirlenmiştir. ${ }^{86}$ Bir belgede ise, para kaçakçılığı yapan şahısların tabiyetleri, lokasyon bilgileri, yakalandıkları yeri belirten bilgiler mevcuttur.

Tablo 7: Para Kaçakçıları

\section{Para Kaçakçıları ${ }^{87}$}

\section{Tüccar}

Kefalonyalı Nikolaki Levani

Elzoni Lafza Zantali

Anazlı Enastasi Moridi

Zantali Muşaki

Kefalonyalı Dimitri Endepe

Acı Nikoli Foktü

SimiristiElenazlı

Yakomi Mavrokordati

Enastasi Kondopolu

Ac1 Dimitri Kosti

Tüfenkcioğlu Corci

Dolma'nın yanında büyük Kurki'nin karındaşı

Nikoli Elinas

Yetali

$\begin{array}{ll}\text { Yakalandı̆̆ı Yer } & \text { Tabiiyeti } \\ \text { Hobar Hanı } & \text { İngiltere } \\ \text { Hobar Hanı } & \text { İngiltere } \\ \text { Hobar Hanı } & \text { İngiltere } \\ \text { Hobar Hanı } & \text { İngiltere } \\ \text { Hobar Hanı } & \text { İngiltere } \\ \text { Hobar Hanı } & \text { İngiltere } \\ \text { Hobar Hanı } & \text { Kuşadası } \\ \text { Hobar Hanı } & \text { Rusya } \\ \text { Hobar Hanı } & \text { Rusya } \\ \text { Hobar Hanı } & - \\ \text { Hobar Hanı } & \text { İzmir } \\ \text { Kurşunlu müfrezesi } & \text { Sardunyalı } \\ \text { Kurşunlu müfrezesi } & - \\ \text { Palaş hanı } & \text { İngiltere }\end{array}$

\footnotetext{
${ }^{83}$ Harice çıkarılması yasaklanan hatta sahilden iç kısımlara gönderilmesi sınırlı ve izne tabi olan bakır sikkeleri kaçak olarak götürenler hakkında yasal takibatın yapılmasına dair. BOA, A.\} MKT.NZD. 390/74, 6/B/1278.(H); BOA, A.\} MKT.UM. 507/53, 14/R/1278.(H).

${ }^{84}$ Bazı sarraf ve tacirlerin delip sildiği altın ve gümüş sikkelerin ve Avrupa'dan kaçak getirilen noksan ayarlı altın mücevverat ve sahte mecidilerin bankalar yoluyla ahaliye dağıtılarak haksız kazanç sağlanması... BOA, DH.MKT. 2415/31, 22/C/1318.(H).

${ }^{85}$ BOA, HR.SFR. 35/8 Tarih yoktur; BOA, HR.SFR. 35/26 Tarih yoktur.

${ }^{86}$ Erler ve Ünlü, "Refuges in The Basin of The Canik Mines: Greek Orthodox From Mining to Agriculture (17901884)", s.191.

87 BOA, HAT. 567/27803, 29/Z/1245.(H).
} 
Sakızlı Galti Frenk Kayafte

İzmirli Sinan oğlu Elniyas

Musa

Sakılı Meke Kofalı Elyanas

Aslı ermeni sikke serîkacısı Maraf Ekinli Nişan

Uzun Cüzeb Katolik DaniMarkali

Lorandaki karındaşı birisi Koru Panayir'in eniştesi

Rubin

Tatavlalı Kastatin Divreli'nin oğlu Yako ve diğer şeriki Estafani ve Fondapoli'nin oğlu Yanko

Korti

Nemçeli Kamanto

Nemçeli Kozga

Sakızlı Damyano

Pazalosun

Kalarolni

Sakızlı Vekozi

Çeçelya

Sakızlı Şakari

DatiTomazi

ÇeknoreliZino

Enfaki

Sarı Kurdi ve karındaşı Elinezli

Tatavlali Yani

K1z1l Endonaki

Bükreşli Altunoğlu Migırdıç zatı Ruscuk Ermenilerinden olup Rusya himayesinde olduğunu haber verir imiş

\begin{tabular}{|c|c|}
\hline Palaş hanı & Sak1z \\
\hline Palaş hanı & İzmir \\
\hline $\begin{array}{l}\text { GaladaniDavir'in } \\
\text { karşısında }\end{array}$ & Yahud \\
\hline Zincirli hanı & - \\
\hline- & Rusya \\
\hline- & - \\
\hline Karaköy’de Sepet hanının karşısında & - \\
\hline Çararcı Hanı & Fransa \\
\hline
\end{tabular}

Zincirlihan karşısı

Validehanı

Yüksek Kaldırım

Perşembe Pazarı

Fransa

Sekpos hanı

Nemçeli

Yüksek Kaldırım

Nemçeli

Perşembe Pazarı

Fransa

Perşembe Pazarı

Fransa

Rusya

Karaköy

Cenevreli

Zincirli Han

Çadırcı Hanı

Hubar hanı

Nemçeli

Osmanlı Devletinde maden kaçakçılığı, uzun bir dönemi kapsamakla beraber XIX. yüzyıl ve XX. yüzyılın başlarında Trabzon Vilayeti dâhilindeki madenlerin durumlarının iyi olmaması maden kaçakçıllk faaliyetlerine az da olsa sekte vurmuştur. Çünkü işlenemeyen madenlerden 
kaçakçılar bile randıman alamamışlardır. Ancak bu bile kaçakçılığı tamamen engellememiş yukarıda bahsedildiği gibi birçok yöntem ve tür geliştirmişlerdir.

\section{Köle Kaçakçılığı}

Osmanlı Devleti’nde, çağdaşı olan devletlerde olduğu gibi köle kullanımı ve köle ticareti mevcuttu. ${ }^{88}$ Köleler Avrupa'da bir ticari meta olarak görülürken Osmanlı Devleti'nde köle kullanımı diğer devletlerden farklı olarak ayrı hukuki mahiyetlere sahipti. ${ }^{89}$ Fakat bu durum Osmanlı Devleti'nde köle kullanımının ve ticaretinin yapıldığı gerçeğini de değiştirmiyordu. Karadeniz'in kuzey ve güneyi köle ticaretinde etkin bir konuma sahipti. ${ }^{90} \mathrm{Bu}$ sebeple Osmanl1 Devleti'nin farklı merkezlerinde esir/köle pazarları kurulmaya başlanmıştır. ${ }^{91}$ XIX. yüzyılın başlarından itibaren Avrupa'da kölecilik yavaş yavaş yasaklanmaya başlanmıştı. Osmanlı Devleti de Avrupalı devletlerle yapılan mülakatlar sonucu aynı kararı almakta gecikmedi. Bunun neticesinde köle ticareti hakkında bir yasaklama gelmiştir. ${ }^{92}$ Yasaklamanın ardından 28 Aralık 1846 tarihinde İstanbul'da bulunan esir pazarı kapatılmıştır. ${ }^{93}$ Köle ticareti yasaklandığ 1 için artık getirilen köleler hükümet tarafindan yasadışı ilan edildiğinden bu ticaret kaçak kabul ediliyordu. ${ }^{94}$ Ancak bu yasağa rağmen bazı esirciler bu işi kendi evlerinde, bazıları da Fatih Camii civarı ile Tophane Semtinde kaçak olarak sürdürmüşlerdir. ${ }^{95}$ XIX. yüzyıl ilk çeyreğinden sonra yapılan köle ticaretiyle ilgili yasaklamalar Kafkasya ve Karadeniz Bölgelerinde hemen uygulanamamıştır. Kırım Savaşı ve 1864 tarihli Çerkez sürgünüyle kaçak köle ticareti artarak devam etmiştir. ${ }^{96}$ Hatta Rus baskısından kaçan Çerkezlerin Trabzon ve Samsun çevresine yerleştirilerek yoksul olanlar için esir pazarları kurulmuştur. ${ }^{97}$ Avrupa'da köleliğin kaldırılması 1890 tarihli Brüksel Konferans $1^{98}$ ve 1919 tarihli Saint-Germain Sözleşmesinde yer ald1. ${ }^{99}$ Bunun üzerine Osmanlı Devleti Çerkez Köle Ticaretini 27 Ekim 1909 tarihinde tamamen yasaklamıştır. ${ }^{100}$

Belgelerde kaçak köle ve kaçakçılık konusu, Türkçenin zengin anlam kapasitesinden dolayı zaman zaman aynı anlama gelebilecek şekilde kullanılması bu konu hakkında anlam karmaşasına neden olabilir. Ele alınan köle kaçakçılığı konusu, resmi yoldan yapılan köle ticaretinin yasaklanması veya elde edilen kölelerin illegal yollarla satılmasını ifade etmekteydi. Kaçak köle

\footnotetext{
${ }^{88}$ Köle kullanımı ve ticaretinin yapılması, bazı belgelerde esir ticareti ve kullanımı olarak görülmektedir.

89 Rüveyda Sağlam İnce, "Kur'an-1 Kerim'de Kölelik Konusu”, (Yayımlanmamış Yüksek Lisans Tezi), Ankara Üniversitesi Sosyal Bilimler Enstitüsü, Ankara 2010, s. 68-120.

${ }^{90}$ BOA, HR.İD. 162/18, 4/S/1857. (H); BOA, MKT.UM. 82/6, 8/M/1268.; Ayrıca bu konu hakkında bir çalıșma, Hasan Kanbolat ve Erol Taymaz, "Kafkas-Osmanlı İlişkileri ve Köle Ticareti”, Tarih Toplum, 14/79, 1990, s. 37.

91 İsmail Parlatır, "Osmanlı Sosyal Hayatından Köleliğin Kaldırılışı”, Ankara Üniversitesi DTCF Dergisi, 31/1, 1987, s. 41.

${ }^{92}$ BOA, HAT. 1169/46238, 15/M/1253(H); Başka bir belgede ise; Rus elçisinin, Trabzon valisine bir ricası kayıt altına alınmıştır. Bazı Samsun ve Sinop gemicileriyle, ecnebi gemicilerin esir ticareti için Rusya'ya götürdükleri esirlerin ticaretine müsaade edilmemesi ve bunun men edilmesine dair. BOA, HAT. 1169/46238, 29/Z/1253.(H).

${ }^{93}$ Z. Güneş, Yağcı, "Karadeniz Köle Ticareti”, Tarih Boyunca Karadeniz Ticareti ve Canik, Osman Köse (der.), Canik Belediyesi Kültür Yayınları, II, Samsun 2013, s.1013.

${ }^{94}$ Osmanlı Devleti köle kaçakçılığını ve illegal köle mevcudiyetini önlemek için çeşitli tedbirler almıştır. Ayrıntılı bilgi için bkz. Gülnihâl Bozkurt, "Osmanlı Devletinde Köle Ticaretinin Önlemesi İçin Yapılan Çalışmalar”, XI. Türk Tarih Kongresi, IV, 1990, s. 1501.

${ }^{95}$ Nihat Engin, "Köle”, Türkiye Diyanet Vakfi İslam Ansiklopedisi, Türkiye Diyanet Vakfi, XXVI, Ankara 2002, s. 248.

${ }^{96}$ BOA, A.) MKT. MHM. 335/87, 28/M/1282.(H).

${ }^{97}$ Parlatır, "Osmanlı Sosyal Hayatından Köleliğin Kaldırılışı", s.420.

${ }^{98}$ Kont Herbert de Bismark'ın Brüksel Konferansın'da köle ticareti aleyhindeki konuşması için; BOA, HR. SYS. 17/62, 8/11/1889.

${ }^{99}$ Güven Dinç ve Cemil Çelik, “Kıbrıs’ta Kölelik(1800-1878)”, Uluslararası Sosyal Araştırmalar Dergisi, 5/23, 2012, ss.186-195. s.187.

${ }^{100}$ Köleliğin tamamen kaldırılması konusunda memleketin çeşitli yerlerinde şikâyetler gelerek esir, köle ve cariyeler hakkında ne tür muamelenin yapılması gerektiğine dair bir belge; BOA, DH. MUİ. 7/24, 1/N/1328.
} 
ise, sahibinden veyahut esir pazarlarından kaçan ve bir yerlere saklanan anlamında kullanılmıştır. ${ }^{101}$ Sonuç olarak kölecilik ve köle ticaretinin bulunması ve buna yasakların getirilmesi tarihi bir süreçtir. Bu süreç içerisine dâhil olan köle kaçakçılığı da, ticaretinin yapıldığı bölgelerde kayıt altına alınmıştır.

\section{SONUÇ}

XIX. yüzyıl ile birlikte karada şose yollar ayrıca demir yollarının faaliyete geçmesi deniz taşımacılığında ise buharlı gemi taşımacılığının deniz nakliyesini daha güvenli ve daha yüksek tonajlarda gerçekleştirmesi nedeniyle klasik dönemde cüzi miktarlarda yapılan kaçakçılık artık büyük miktarlara yükselmiştir. Bu duruma bir de Osmanlı Devleti'nin Karadeniz'i uluslararası ticarete açması, kapitülasyon sistemi ve yapılan ticaret anlaşmalarıyla ihracat yasaklamalarına yönelmesi kaçakçıllğın artmasına neden olan başka bir etken olmuştur. Özellikle Osmanlı Devleti'nin borçlarının Duyun-1 Umumiye'ye terki ve bu kurumun Osmanlı borçlarına karşılık olarak almış olduğu gelir kalemlerinden sonra tuz ve tütün kaçakçılığında artış görülmüştür. Silah kaçakçılığı ise, XIX. yüzyılda Ermeni, Rum, Sırp, Arnavut, Karadağ gibi ayrılıkçı faaliyetlerinde kullanıldığı için devletin parçalanmasında etki sahibi olmuştur. Maden kaçakçılığı ise devletin ekonomik olarak zor duruma düşürmesine rağmen kaçakçılara karşı uygulanan cezai işlemler pek caydırıcı oranda olmamıştır. Bu durum maden ve türevlerinin kaçırılması faaliyetlerini ortadan kaldırmaya yetmemiştir. Köle kaçakçılığında durum köleliğin ortadan kaldırılmasına kadar devam edegelmiştir. Köle kaçakçılığı ve köleliğin kaldırılması sürecinde Avrupa etkisi önemli rol oynamıştır. Kaçakçılar, kaçırdıkları emtiaları istedikleri şekilde istenilen adreslere ulaştırmışlardır tabi ki bu durumda devlet ile karşı karşıya kalarak silahlı çatışmalarda meydana gelmiştir.

\section{KAYNAKÇA \\ Arşiv Belgeleri}

Cumhurbaşkanlı̆̆ı Osmanlı Arşivi (BOA)

Bâbıâlî Evrak Odası Defterleri (BEO)

Dahiliye Nezâreti Emniyet-i Umumiye Müdüriyeti (DH.EUM)

Dahiliye Nezâreti İdarî Kısım Belgeleri (DH. ID)

Dahiliye Nezâreti Mektubî Kalemi (DH.MKT.)

Dahiliye Nezâreti Tesrî-i Muamelât ve Islahat Komisyonu, Muamelât (DH. TMIK. M.)

Hariciye Nezareti Hukuk Müşavirliği İstişsare Odası Belgeleri (HR.HMŞ.IŞSO)

Hariciye Nezareti İdare Kalemi Belgeleri (HR.ID.)

Hariciye Nezareti Sefaretler (HR.SFR.)

Hariciye Nezareti Siyasî Kısmı Belgeleri (HR. SYS.)

Hariciye Nezareti Tahrirât-ı Hariciye Belgeleri (HR.TH)

Hatt-ı Hümâyûn (HAT.)

${ }^{101}$ M. Salih Erkek, "Eski Yakındoğu'dan Osmanlı'ya Kaçak Köleliğin Tarih Yazımı ve Üsküdar'da Kaçak Köleler (1523-1529)", Turkish Studies, 12/19, 2017, s. 61.

Near East Historical Review

www.nehrreview.com 
Irâde Dahiliye (i..DH)

İâde Şûrâ-yı Devlet (İ.ŞD.)

Mâbeyn Başkitâbeti (Y..PRK.BŞK)

Maliye Nezâreti Maruzâtı (Y.PRK.ML)

Meclis-i Vükelâ Mazbataları (MV.)

Muallim Cevdet Tasnifi Belgeleri Darbhâne (C.DRB)

Muhaberât-ı Umumiye İdaresi Belgeleri (DH.MUI)

Mühimme Defterleri (A.\{DVNS.MHM.d.)

Sadâret Mektubî Kalemi Meclis-i Vâlâ Belgeleri (A.jMKT.MVL)

Sadâret Mektubî Kalemi Mühimme Odası (Kalemi) Belgeler (A.jMKT.MHM.)

Sadâret Mektubî Kalemi Nezâret ve Devâir Belgeleri (A.jMKT.NZD)

Sadâret Mektubî Kalemi Umum Vilayet Belgeleri (A.\}MKT.UM)

Şifre Kalemi Belgeleri (DH.ŞFR.)

Şûrâ-yı Devlet Belgeleri (ŞD)

Umum Vilayetler Tahrirâtı (Y..PRK.UM.,)

Yıldız Sadâret Hususî Maruzât Evrakı (Y..A...HUS)

Zabtiye Nezâreti (ZB.)

\section{Salnameler}

Trabzon Vilayet Salnamesi

1878, 1894, 1898, 1901, 1902, 1903, 1904.

Şark Ticaret Yıllıkları

Annuaire Oriental, 1902.

\section{Kitaplar}

Doğruel, Fatma ve Doğruel, Suut, Osmanlıdan Günümüze Tütün, Tekel/Tütün Vakf1, İstanbul 2000.

E.Keskin Nuray ve Yaman, Melda, Türkiye'de Tütün: Reji'den Tekel'e Tekel'den Bugüne, Notabene Yayınları, Ankara 2013.

Faroqhı, Suraıya, Osmanlı'da Kentler ve Kentliler, Neyyir Kalaycıoğlu (çev.), Tarih Vakfı Yurt Yayınları, İstanbul 1994.

Güran, Tevfik 19. Yüzyılda Osmanlı Ekonomisi Üzerine Araştırmalar, Türkiye İş Bankası Kültür Yayınları, İstanbul 2014.

İnalcık Halil ve Anheger, Robert Kânûnnâme-i Sultanî BerMûceb-i Örf-i Osmanî, Türk Tarih Kurumu, Ankara 1956.

Kırkbıyı, Emin, Mazide Kalan Reji, Samsun Eğitim Derneği Yayınları, Samsun 2013. 
Muâhedât Mecmûası, Türk Tarih Kurumu, 5 Cilt, Ankara 2008.

Quataert, Donald Osmanlı Devleti'nde Avrupa Ikktisadi Yayılımı ve Direniş 1881-1908, Sabri Tekay (çev.), İletişim Yayınları, İstanbul 2017.

\section{Makaleler}

Boyacıŏlu, Didem, “Tanzimat'tan Cumhuriyet'e Osmanlı Fabrika Yapılarının İnşasına Dair Yapılan Düzenlemeler”, Uluslararası Sosyal Araştırmalar Dergisi, 8/38, 2015, ss. 471-486.

Demirel, Fatmagül, "Osmanlı Devleti'nde Tuz Gelirlerinin Düyûn-1 Umûmiye’ye Devredilmesinden Sonra Tuz Kaçakçılı̆̆ı”, Tuz Kitabı, Emine Gürsoy Naskali, Mesut Şen (der.), Kitabevi, İstanbul 2004. ss.299-305.

Dinç, Güven ve Çelik, Cemil, “Kıbrıs’ta Kölelik(1800-1878)”, Uluslararası Sosyal Araştırmalar Dergisi, 5/23, 2012, ss.186-195.

Erim, Neşe, “18. Yüzyılda Erzurum Tuzlaları”, Tuz Kitabl, Emine Gürsoy Naskali,

Erkek, M. Salih, “Eski Yakındoğu'dan Osmanlı'ya Kaçak Köleliğin Tarih Yazımı ve Üsküdar'da Kaçak Köleler (1523-1529)", TurkishStudies, 12/19, 2017, ss.61-90.

Erler M. Yavuz, ve Ünlü, Mucize, "Refuges in thebasin of the Canik Mines: Greek Orthodox from Mining to Agriculture (1790-1884)", Black Sea History, V, 2015, ss. 185-220.

Erler, M. Yavuz, “İstanbul'da Deniz Ulaşımı (1870-1875)”, Osmanlı Araştırmaları, XXI, 2001, ss.69-80.

Gölbaş, Alper ve Başıüyük, Zeynel, “Anadolu Kültür Oluşumunda Tuzun Rolü”, Batman Üniversitesi Yaşam Bilimleri Dergisi, 1/1, 2012, ss.45-54.

Güçer, Lütfi "XV-XVII. Asırlarda Osmanlı İmparatorluğunda Tuz İnhisarı ve Tuzlaların İşletme Nizamı" İstanbul Üniversitesi İktisad Fakültesi Mecmuası, 23/1-2, 1963, ss.97-143.

Kanbolat, Hasan ve Taymaz, Erol, "Kafkas-Osmanlı İlişkileri ve Köle Ticareti”, Tarih Toplum, $14 / 79,1990$, ss.35-44.

Kasım, Ekin, “1862 Tuz Nizamnamesi ve Önemi”, Gazi Üniversitesi Sosyal Bilimler Dergisi, 3/7, 2016, ss.1-30.

Mesut Şen (ed.), Kitabevi, İstanbul 2004, ss. 241-247.

Narin, Resül, "Düyûn-1 Umûmiye İdaresi ve Adapazarı", Karadeniz Araştırmaları Dergisi, 6/21, 2009, ss.49-59.

Özkan, S. Hilmi, "Arms Smuggling Across Ottoman Borders in the Second Half of the 19th Century", Journal of Balkan and Near Eastern Studies, 18/3, 2016, ss.297-312.

Parlatır, İsmail, "Osmanlı Sosyal Hayatından Köleliğin Kaldırılışı”, Ankara Üniversitesi DTCF Dergisi, 31/1, 1987, ss. 417-420.

Uygun, Süleyman, "Paquet Vapur Nakliyat Kumpanyası (Compagnie De Navigatıon Paquet) Ve Osmanlı Ermenileri”, A. Ü. Türkiyat Araştırmaları Enstitüsü Dergisi, S.56, 2016, ss. $1339-1363$.

Ünal, M. Ali, “17. Yüzyılda Karadeniz'de Kazak Saldırıları ve Karadeniz Ticareti”, Tarih Boyunca Karadeniz Ticareti ve Canik, Osman Köse (der.), Canik Belediyesi Kültür Yayınları, II, Samsun, 2013, ss. 853-856. 
Yağc1, Z. Güneş, “Karadeniz Köle Ticareti”, Tarih Boyunca Karadeniz Ticareti ve Canik, Osman Köse (der.), Canik Belediyesi Kültür Yayınları, II, Samsun 2013, ss.999-1024.

Yılmaz, Özgür, "19. Yüzyılda Trabzon'da Fransız Ticareti ve Yatırımları", Karadeniz Incelemeleri Dergisi, 8/15, 2013, s.39-76.

\section{Ansiklopedi Maddeleri}

Engin, Nihat, "Köle", Türkiye Diyanet Vakfi İslam Ansiklopedisi, Türkiye Diyanet Vakfi, XXVI, Ankara 2002, ss.237-248.

Kurdakul, Necdet, "Ticaret Antlaşmaları", Tanzimat'tan Cumhuriyet'e Türkiye Ansiklopedisi, İletişim Yayınları, III, İstanbul 1985, ss.666-667.

\section{Kongre ve Sempozyum Bildirileri}

Bozkurt, Gülnihâl, “Osmanlı Devletinde Köle Ticaretinin Önlemesi İçin Yapılan Çalışmalar”, XI. Türk Tarih Kongresi, IV, 1990, ss.1499-1531.

Genç, Mehmet, "17.-19. Yüzyıllarda Sanayi ve Ticaret Merkezi Olarak Tokat”, Türk Tarihinde ve Kültüründe Tokat Sempozyumu, 1986, ss. 145-169.

Arıkan, Ahmet Saim “Türk Deri İşlemeciliği Bağlamında Türk Cild Sanatı”, Uluslararası Asya ve Afrika Çalışmaları Kongresi, C.I, 2008, ss. 121-136.

\section{Yayınlanmamış Lisansüstü Tezler}

Hamzaoğlu, Kubilay, Trabzon Vilayeti'nde Kaçakçılık (1855-1908), (Yayımlanmamış Yüksek Lisans Tezi), Ondokuz Mayıs Üniversitesi Sosyal Bilimler Enstitüsü, Samsun 2019.

İnce, Rüveyda Sağlam, Kur'an-ı Kerim'de Kölelik Konusu, (Yayımlanmamış Yüksek Lisans Tezi), Ankara Üniversitesi Sosyal Bilimler Enstitüsü, Ankara 2010.

İnce, Yunus, Osmanlı Barut Üretim Teknolojisinde Modernleşme: Azadlu Baruthanesi (17941878), (Yayınlanmamış Doktora Tezi), Selçuk Üniversitesi Sosyal Bilimler Enstitüsü, Konya 2013.

Uzun, Musa, 1924/110 No'lu Trabzon Şer'iyye Sicil Defterinin Transkripsiyonu ve Tahlili, (Yayınlanmamış Yüksek Lisans Tezi), Ondokuz Mayıs Üniversitesi Sosyal Bilimler Enstitüsü, Samsun 2007. 